\title{
Injuries and molting interference in a trilobite from \\ the Cambrian (Furongian) of South China (\#55705)
}

First revision

\section{Guidance from your Editor}

Please submit by 6 Mar 2021 for the benefit of the authors .

\section{Structure and Criteria}

Please read the 'Structure and Criteria' page for general guidance.

\section{Raw data check}

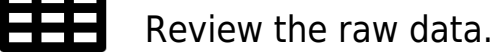

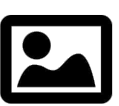

\section{Image check}

Check that figures and images have not been inappropriately manipulated.

Privacy reminder: If uploading an annotated PDF, remove identifiable information to remain anonymous.

\section{Files}

Download and review all files from the materials page.
1 Tracked changes manuscript(s)

1 Rebuttal letter(s)

3 Figure file(s) 


\section{Structure your review}

The review form is divided into 5 sections. Please consider these when composing your review:

\section{BASIC REPORTING}

2. EXPERIMENTAL DESIGN

3. VALIDITY OF THE FINDINGS

4. General comments

5. Confidential notes to the editor

You can also annotate this PDF and upload it as part of your review

When ready submit online.

\section{Editorial Criteria}

Use these criteria points to structure your review. The full detailed editorial criteria is on your guidance page.

\section{BASIC REPORTING}

Clear, unambiguous, professional English language used throughout.

Intro \& background to show context. Literature well referenced $\&$ relevant.

Structure conforms to Peer] standards, discipline norm, or improved for clarity.

Figures are relevant, high quality, well labelled \& described.

Raw data supplied (see Peer] policy).

\section{EXPERIMENTAL DESIGN}

Original primary research within Scope of the journal.

Research question well defined, relevant \& meaningful. It is stated how the research fills an identified knowledge gap.

Rigorous investigation performed to a high technical \& ethical standard.

Methods described with sufficient detail \& information to replicate.

\section{VALIDITY OF THE FINDINGS}

Impact and novelty not assessed.

Negative/inconclusive results accepted. Meaningful replication encouraged where rationale $\&$ benefit to literature is clearly stated.

All underlying data have been provided; they are robust, statistically sound, $\&$ controlled.
Speculation is welcome, but should be identified as such.

Conclusions are well stated, linked to original research question $\&$ limited to supporting results. 


\section{Standout \\ reviewing tips}

The best reviewers use these techniques

Tip

\section{Support criticisms with evidence from the text or from other sources}

\section{Give specific suggestions on how to improve the manuscript}

\section{Comment on language and grammar issues}

\author{
Please provide constructive \\ criticism, and avoid personal \\ opinions
}

\section{Example}

Smith et al (J of Methodology, 2005, V3, pp 123) have shown that the analysis you use in Lines 241-250 is not the most appropriate for this situation. Please explain why you used this method.

Your introduction needs more detail. I suggest that you improve the description at lines 57- 86 to provide more justification for your study (specifically, you should expand upon the knowledge gap being filled).

The English language should be improved to ensure that an international audience can clearly understand your text. Some examples where the language could be improved include lines 23, 77, 121, 128 - the current phrasing makes comprehension difficult.

1. Your most important issue

2. The next most important item

3....

4. The least important points

I thank you for providing the raw data, however your supplemental files need more descriptive metadata identifiers to be useful to future readers. Although your results are compelling, the data analysis should be improved in the following ways: $A A, B B, C C$

I commend the authors for their extensive data set, compiled over many years of detailed fieldwork. In addition, the manuscript is clearly written in professional, unambiguous language. If there is a weakness, it is in the statistical analysis (as I have noted above) which should be improved upon before Acceptance.
Comment on strengths (as well as weaknesses) of the manuscript 


\section{Injuries and molting interference in a trilobite from the Cambrian (Furongian) of South China}

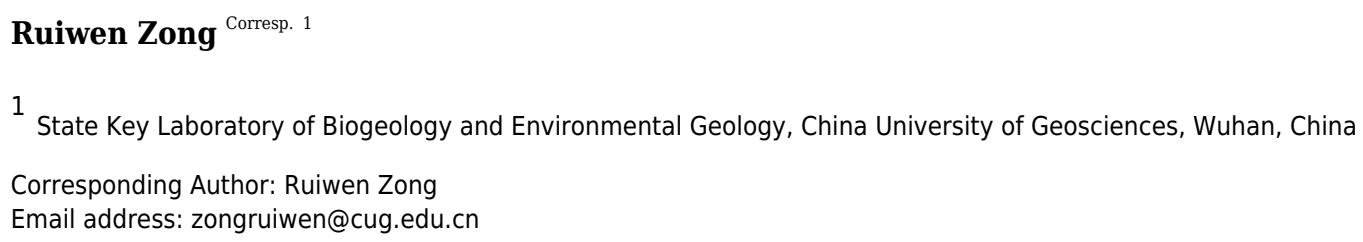

An injured Shergoldia laevigata Zhu, Hughes \& Peng 2007 (Trilobita, Asaphida) was collected from the Furongian of Guangxi, South China. The injuries occurred in the left thoracic pleurae possessing two marked V-shaped gaps. It led to substantial transverse shortening of the left pleural segments, with barely perceptible traces of healing. This malformation is interpreted as a sub-lethal attack from an unknown predator. The morphology of the injuries and the spatial and temporal distribution of predators indicated that the predatory structure might have been the ganathobase or ganathobase-like structure of a larger arthropod. There were overlapped somites located in the front of the injuries, and slightly dislocated thoracic segments on the left part of the thorax, suggesting that the trilobite had experienced difficulties during the molting process. The freshly molted trilobite had dragged forward the old exuvia causing the irregular arrangement of somites. This unusual trilobite specimen indicates that the injuries interfered with molting. 


\section{Injuries and molting interference in a trilobite from the}

\section{Cambrian (Furongian) of South China}

3

4 Ruiwen Zong

5

6 State Key Laboratory of Biogeology and Environmental Geology, China University of

7 Geosciences, Wuhan, Hubei, China

8

9 Corresponding Author:

10 Ruiwen Zong

11 Lumo Road No. 388, Wuhan, Hubei, 430074, China

12 Email address: zongruiwen@cug.edu.cn
14

15

\section{Abstract}

An injured Shergoldia laevigata Zhu, Hughes \& Peng 2007 (Trilobita, Asaphida) was collected from the Furongian of Guangxi, South China. The injuries occurred in the left thoracic pleurae possessing two marked V-shaped gaps. It led to substantial transverse shortening of the left pleural segments, with barely perceptible traces of healing. This malformation is interpreted as a sub-lethal attack from an unknown predator. The morphology of the injuries and the spatial and temporal distribution of predators indicated that the predatory structure might have been the ganathobase or ganathobase-like structure of a larger arthropod. There were overlapped somites located in the front of the injuries, and slightly dislocated thoracic segments on the left 
23 part of the thorax, suggesting that the trilobite had experienced difficulties during the molting

24 process. The freshly molted trilobite had dragged forward the old exuvia causing the irregular

25 arrangement of somites. This unusual trilobite specimen indicates that the injuries interfered with

26 molting.

27 Introduction

28 Numerous trilobite exoskeleton deformities have been documented, including abnormal 29 healing, hyperplasia, deformation, and missing or fractured somites. The causes of these 30 deformities are usually thought to be injuries, developmental disorders, and diseases (Owen, 31 1985; Babcock, 1993; Pates et al., 2017; Bicknell \& Pates, 2020). The evaluation of injuries 32 caused by predator attack is useful for presenting the interactions between predators and 33 trilobites, and for reconstructing the food web and ecological structure in deep time 34 (Klompmaker et al., 2019). Furthermore, such predatorial injuries are used to uncover behavioral information (Babcock \& Robison, 1989; Babcock, 1993; Pates et al., 2017; Bicknell, Paterson \& Hopkins, 2019). The injuries caused by predators have mainly been detected on the edges of trilobites, especially in the thoraces and pygidia, and are generally considered to have been nonlethal (Babcock, 2003, 2007), while cephalic attacks are more often fatal (Pates \& Bicknell, 2019). Although numerous studies have evaluated injured trilobites (e.g., Owen, 1985; Rudkin, 1985; Babcock, 1993, 2003, 2007; Zhu et al., 2007; Schoenemann, Clarkson \& Høyberget, 2017; Bicknell \& Paterson, 2018; Bicknell \& Pates, 2020; Bicknell \& Holland, 2020; Zong, 2020), most predators remain unidentified, except some carnivores with trilobite fragments in their guts or coprolites (Vannier \& Chen, 2005; Vannier, 2012; Zacaï, Vannier \& Lerosey-Aubril, 2016; Bicknell \& Paterson, 2018; Kimmig \& Pratt, 2018). The shapes of the Cambrian trilobite injuries suggest that some predators may have been radiodonts (Babcock \& Robison, 1989; Babcock, 
46 1993; Nedin, 1999). Other predator candidates include cephalopods, echinoderms, fish, and other

47 larger arthropods (Bruton, 1981; Briggs \& Collins, 1988; Babcock, 1993; Fatka, Budil \& Grigar, 48 2015; Jago, García-Bellido \& Gehling, 2016; Bicknell \& Paterson, 2018; Bicknell et al., 2018a; 49 Zhai et al., 2019).

50 Moreover, although it has been inferred that injuries did interfere with daily activities of 51 trilobites, direct fossil records are rare (Šnajdr, 1985). Herein, I discuss an injured Shergoldia 52 laevigata Zhu, Hughes \& Peng 2007 from the Cambrian (Furongian) of Jingxi, Guangxi, South 53 China. The exoskeletal injuries suggest that the predatory structure might have been the 54 gnathobase or gnathobase-like structure of a larger arthropod. In addition, the findings indicate 55 that these injuries would have caused difficulties for trilobite during molting, but did not cause 56 molting failure.

\section{Materials \& Methods}

The described Shergoldia laevigata specimen, housed in the State Key Laboratory of

59

60

61 62

Biogeology and Environmental Geology, China University of Geoscience (Wuhan), was discovered from the Cambrian (Furongian)-aged Sandu Formation of Guole Town, Jingxi County, Guangxi Zhuang Autonomous Region, South China (Fig. 1) (Zhu, Hughes \& Peng, 2007). The Sandu Formation is represented by calcareous mudstones, siltstones, and argillaceous banded limestones, which formed most probably in the uppermost part of the continental slope (Lerosey-Aubril, Zhu \& Ortega-Hernández, 2017). The Sandu Formation is richly fossiliferous, containing abundant, well-preserved articulated trilobites (Han et al., 2000; Zhu, 2005; Zhu, Hughes \& Peng, 2007, 2010), non-trilobite arthropods (Lerosey-Aubril, Ortega-Hernández \& Zhu, 2013; Lerosey-Aubril, Zhu \& Ortega-Hernández, 2017), echinoderms (Han \& Chen, 2008; Chen \& Han, 2013; Zamora et al., 2017; Zamora, Zhu \& Lefebvre, 2013; Zhu, Zamora 
$69 \&$ Lefebvre, 2014), brachiopods, graptolites (Zhan et al., 2010), hyolithids, cnidarians, algae, and

70 some exceptionally preserved soft-bodied fossils (Zhu et al., 2016).

71 Trilobites from the Sandu Formation have been classified into at least 25 genera ( $\mathrm{Zhu}, 2005$;

72 Zhu, Hughes \& Peng, 2007, 2010); however, only six abnormal specimens have been

73 documented from this formation (five Tamdaspis jingxiensis Zhu et al., 2007 and one

74 Guangxiaspis guangxiensis Zhou in Zhou et al, 1977) (Zhu, 2005; Zhu et al., 2007; Zong, 2020).

75 The injured Shergoldia laevigata was collected from the grey-yellow calcareous mudstones. The

76 specimen is from the Probinacunaspis nasalis-Peichiashania hunanensis Zone of the Furongian,

77 Jiangshanian (Peng, 2009; Zhu et al., 2016).

78 The fossil in Fig. $2 \mathrm{C}$ was whitened with magnesium oxide powder, and all photographs

79 were captured using a Nikon D5100 camera with a Micro-Nikkor 55 mm F3.5 lens.

\section{Results}

81 The injured Shergoldia laevigata is preserved as a nearly complete dorsal exoskeleton (30.5

$82 \mathrm{~mm}$ long) without librigena, suggesting an exuvia (Daley \& Drage, 2016; Drage, 2019). The

83 posterior of the cranidium overlies the first two thoracic segments, this is most pronounced on

84 the left side (Fig. 2). In addition, the first thoracic segment covered most of the left pleural

85 segment of the second thoracic segment, as well as the anterior margin of the right pleural

86 segment. Similarly, most of the first thoracic segment was covered by the posterior area of the

87 fixigena, particularly on its left side. Moreover, the left pleural segments of the fourth to eighth

88 thoracic segments presented an interlaced arrangement, i.e. the anterior margin of the fourth

89 thoracic segment extended upon the third thoracic segment, and the seventh extended upon the

90 sixth (Fig. 2), while there was a typical imbricated arrangement in the right pleural region. 
91 The malformation is on the left part of the exoskeleton, while the medial (axial) and right

92 sections are undamaged. The left thoracic segments are shorter than those on the right side and

93 show limited healing. There are two injuries: one on the third to fourth thoracic segments, and

94 one on the seventh thoracic segment. Two pleural segments are truncated by $3.3 \mathrm{~mm}$ because of

95 the first injury; the most seriously damaged part is the contact site of the two thoracic segments,

96 where there is a V-shaped injury. The second injury truncates the left pleural section of the

97 seventh thoracic segment by $3.5 \mathrm{~mm}$, with the injury presenting as an asymmetric V-shape.

\section{Discussion}

\section{Possible origin of the injuries and potential predatory structure}

100 Trilobites that are malformed due to predatory attacks have typically V-, U-, or W-shaped

101 injuries (Owen, 1985; Babcock, 1993; Pratt, 1998; Jago \& Haines, 2002; Zamora et al., 2011;

102 Pates et al., 2017; Bicknell \& Paterson, 2018; Bicknell \& Pates, 2020), with a few showing in

103 irregularly shaped injuries (Fatka, Budil \& Grigar, 2015). Furthermore, there is occasionally

104 signs of healing or regeneration (Rudkin, 1979; Mcnamara \& Tuura, 2011; Pates et al., 2017). In

105 the present specimen, the injuries have traces of healing and are therefore considered evidence of

106 a predatory attack. The two injuries have a similar degree of healing without any regeneration,

107 suggesting that these injuries may have been incurred in the same inter-molt stage.

108 In the past, the most suspicious Cambrian predators are considered to have been the

109 radiodonts, especially anomalocaridids and amplectobeluids, as their frontal appendages and oral

110 cone were extremely effective predatory structures (Whittington \& Briggs, 1985; Babcock, 1993;

111 Zamora et al., 2011). Cambrian arthropods or arthropod-like organisms with gnathobases are

112 also considered possible predators, similar to the modern horseshoe crab (Bicknell et al., 2018a,

113 2021). Some amplectobeluid genera have been documented with gnathobase-like structures 
114 (Cong et al., 2017, 2018), suggesting that amplectobeluid radiodonts may have been predators of

115 Cambrian trilobites (Bicknell \& Pates, 2020). In addition, some trilobites and predatory

116 arthropods with reinforced gnathobasic spines on the protopodal sections of their walking legs

117 are also considered as potential predators (Bruton, 1981; Conway Morris \& Jenkins, 1985; Zacaï,

118 Vannier \& Lerosey-Aubril, 2016; Bicknell et al., 2018a, b; Bicknell, Paterson \& Hopkins, 2019;

119 Bicknell \& Holland, 2020).

120 However, so-far, the youngest amplectobeluid and anomalocaridid are from the Drumian 121 and Guzhangian, respectively (Lerosey-Aubril et al., 2014, 2020). Most Furongian and 122 Ordovician radiodonts belong to the family Hurdiidae, which do not have endites of alternating 123 size, and all members of this family are considered to be-sediment sifters or suspension feeders 124 (Daley, Budd \& Caron, 2013; Daley et al., 2013; Lerosey-Aubril \& Pates, 2018; Van Roy, Daley 125 \& Briggs, 2015; Pates et al., 2020). Moreover, no radiodonts were discovered in the Sandu 126 Formation. So, the radiodonts unlikely cause the injuries in the Shergoldia laevigata specimen. 127 Gnathobases have a slight size gradation of spines along the gnathal edge (Stein, 2013), or a saw128 toothed pattern with spines of alternating sizes (Bicknell et al., 2018a). These spines may caused 129 smaller injuries, that is missing one or two separate thoracic segments, on the edges of trilobites. 130 The arthropods Aglaspella sanduensis (Lerosey-Aubril, Ortega-Hernández \& Zhu, 2013) and 131 Glypharthrus trispinicaudatus, Mollisonia-like arthropods, unnamed aglaspidid-like arthropods, 132 Perspicaris-like bivalve arthropods (Zhu et al., 2016; Lerosey-Aubril, Zhu \& Ortega-Hernández, 133 2017), and some larger trilobites $(\mathrm{Zhu}, 2005)$ were discovered in the Sandu Formation at the 134 same site. Therefore, the predator who attacked the studied Shergoldia laevigata specimen 135 maybe one of these arthropods.

\section{Interference with the molting of trilobite}


137 Previous studies have reported abundant injured trilobites and presented the possible 138 identity of the predators, including information about their behavior (Babcock, 1993, 2007; Pates 139 et al., 2017; Bicknell \& Paterson, 2018; Bicknell, Paterson \& Hopkins, 2019; Pates \& Bicknell, 140 2019). However, there are few direct fossil records showing that injury has disturbed the molting 141 of trilobites $(\check{S} n a j d r, 1985)$. The studied specimen has an apparent overlap of somites along with 142 the injuries that are mainly present in the posterior of the cranidium and the front of the thorax, 143 especially in the left part of the exoskeleton. The anterior margin of the injuried third thoracic 144 segment was covered by the unbroken second thoracic segment (Fig. 2A-D), indicating that the 145 injury formed before the overlap of the somites. Bottom currents can also caused the overlap and 146 even disruption of trilobite somites, the Sandu Formation formed in a relatively calm 147 environment (Lerosey-Aubril, Zhu \& Ortega-Hernández, 2017), although there are overlapping 148 segments on the exuvia and carcass of Shergoldia laevigata in the same horizon, their thoracic 149 segments still maintain imbricated arrangement (Zhu, Hughes \& Peng, 2007). There is also 150 overlap of thoracic segments on the exuvia of uninjured trilobites (Daley \& Drage, 2016), but it 151 is difficult to determine whether it was caused by molting or other abiotic factors. In contrast to 152 the above two cases, in addition to the overlap of somites in the studied specimen, the left 153 thoracic segments are presented an interlaced arrangement rather than imbricated (Fig. 2), which

154 155 156 157 158 159 seems not to be caused by bottom currents and is rather likely caused by the active behavior of trilobite. Moreover, all abnormal arrangements of the segments appeared near the injury, and the overlapped part of the somites was only located before the most serious injury (on the third to fourth thoracic segments). It is speculated that all of the irregular patterns were caused by postinjury molting of Shergoldia laevigata. Namely, the new exoskeleton could not be smoothly separated from the old one due to the unbalanced body with injuries (Drage, 2019; Drage et al., 
160 2019). The trilobite dragged forward the old shell to get rid of the exuvia, which led to the

161 overlap of somites and the dislocated arrangement of thoracic segments, especially near the

162 injuries (Fig. 3). Some previous studies have reported cases of failed molting of a trilobite

163 (McNamara \& Rudkin, 1984) and other ecdysozoans (Garcia-Bellido \& Desmond, 2004; Drage

164 \& Daley, 2016; Yang et al., 2019), in which the new exoskeletons were preserved under the old

165 exuvia. However, none of the fragments of the new exoskeleton were found under or near the 166 exuvia of Shergoldia laevigata, which implies that the molting might not have failed. Although

167 the injuries complicated the molting process, it was successful and the molted trilobite moved 168 away.

169 Conclusions

170 The Shergoldia laevigata specimen has substantially shorter pleural segments of the third to 171 fourth and seventh thoracic segments, with signs of lightly healing in the injuries incurred during 172 a sub-lethal predator attack. The degree of healing in both injuries and the distribution of the 173 injuries show that they may have been caused in the same inter-molt stage. Based on the 174 morphology of the injuries and the spatial and temporal distribution of predators, the predatory 175 structure may have been the gnathobase or gnathobase-like structure of a larger arthropod. The 176 conspicuous overlapping of the somites and dislocated arrangement of the thoracic segments, 177 especially in the left pleural region and near the injuries, shows that the injured Shergoldia 178 laevigata encountered certain obstacles during the molting process. The trilobite dragged the old 179 exuvia forward, which lead to the irregular arrangement of the somites. Such configuration can 180 demonstrate that even provisionally healed injury can cause certain complication of the molting 181 process in trilobites.

\section{Acknowledgements}


183 I appreciate much the constructive and critical comments from Russell Bicknell, Stephen Pates,

184 John Foster and one anonymous reviewer, which aided in the further improvement of the 185 manuscript. I would like to thank Guangchun Zeng (from Guangxi), Qi Liu (from Hunan) and 186 Yonggang Tang (from Shandong) for their help in the field work and collection of specimens.

187 References

188 Babcock LE. 1993. Trilobite malformations and the fossil record of behavioral asymmetry. Journal of Paleontology, 67: 217-229 DOI 10.1017/S0022336000032145.

190

191

192

193

194

195

196

197

198

199

200

201

202

203

204

Babcock LE. 2003. Trilobites in Palaeozoic predator-prey systems, and their role in reorganization of early Paleozoic ecosystems. In: Kelly PH, Kowalewski M, Hansen TA, eds. Predator-Prey Interactions in the Fossil Record. New York: Springer, 55-92.

Babcock LE. 2007. Role of malformations in elucidating trilobite paleobiology: a historical synthesis. In: Mikulic DG, Landing E, Kluessendorf J, eds. Fabulous Fossils-300 Years of Worldwide Research on Trilobites. New York: The University of State of New York, 3-18.

Babcock LE, Robison RA. 1989. Preferences of Palaeozoic predators. Nature 337: 695-696 DOI $10.1038 / 337695 \mathrm{c} 0$.

Bicknell RDC, Holland B. 2020. Injured trilobites within a collection of dinosaurs: Using the Royal Tyrrell Museum of Palaeontology to document Cambrian predation. Palaeontologia Electronica 23: a33 DOI 10.26879/1087.

Bicknell RDC, Holmes JD, Edgecombe GD, Losso SR, Ortega-Hernández J, Wroe S, Paterson JR. 2021. Biomechanical analyses of Cambrian euarthropod limbs reveal their effectiveness in mastication and durophagy. Proceedings of the Royal Society B: Biological Sciences 288: 20202075. DOI 10.1098/rspb.2020.2075. 
205 Bicknell RDC, Ledogar JA, Wroe S, Gutzler BC, Watson III WH, Paterson JR. 2018 a.

206 Computational biomechanical analyses demonstrate similar shell-crushing abilities in 207 modern and ancient arthropods. Proceedings of the Royal Society B: Biological Sciences 208 285: 20181935. DOI 10.1098/rspb.2018.1935.

209

210

211

212

213

214

215

216

217

218

219

220

221

222

223

224

225

226

227

Bicknell RDC, Paterson JR. 2018. Reappraising the early evidence of durophagy and drilling predation in the fossil record: implications for escalation and the Cambrian explosion. Biological Reviews 93: 754-784 DOI 10.1111/brv.12365.

Bicknell RDC, Paterson JR, Caron JB, Skovsted CB. 2018b. The gnathobasic spine microstructure of Recent and Silurian chelicerates and the Cambrian artiopodan Sidneyia: functional and evolutionary implications. Arthropod Structure \& Development 47: 12-24 DOI 10.1016/j.asd.2017.12.001.

Bicknell RDC, Paterson JR, Hopkins MJ. 2019. A trilobite cluster from the Silurian Rochester Shale of New York: predation patterns and possible defensive behavior. American Museum Novitates 39: 1-16 DOI 10.1206/3937.1.

Bicknell RDC, Pates S. 2020. Exploring abnormal Cambrian-aged trilobites in the Smithsonian collection. PeerJ 8: e8453 DOI 10.7717/peerj.8453.

Briggs DEG, Collins D. 1988. A Middle Cambrian chelicerate from Mount Stephen, British Columbia. Palaeontology 31: 779-798.

Bruton DL. 1981. The arthropod Sidneyia inexpectans, Middle Cambrian, Burgess Shale, British Columbia. Philosophical Transactions of the Royal Society of London. Series B, Biological Sciences 295: 619-656 DOI 10.1098/rstb.1981.0164.

Chen GY, Han NR. 2013. New materials of Stylophora from the Upper Cambrian of the Jingxi area, Guangxi, South China. Acta Palaeontologica Sinica 52: 288-293. 
228 Cong PY, Daley AC, Edgecombe GD, Hou, XG. 2017. The functional head of the Cambrian 229 radiodontan (stem-group Euarthropoda) Amplectobelua symbrachiata. BMC Evolutionary 230

231

232

233

234 Biology 17: 208. DOI 10.1186/s12862-017-1049-1.

Cong PY, Edgecombe GD, Daley AC, Guo J, Pates S, Hou XG. 2018. New radiodonts with gnathobase-like structures from the Cambrian Chengjiang biota and implications for the systematics of Radiodonta. Papers in Palaeontology 4: 605-621 DOI 10.1002/spp2.1219.

Conway Morris S, Jenkins RJF. 1985. Healed injuries in Early Cambrian trilobites from South Australia. Alcheringa 9: 167-177 DOI 10.1080/03115518508618965.

Daley AC, Budd GE, Caron JB. 2013. Morphology and systematics of the anomalocaridid arthropod Hurdia from the Middle Cambrian of British Columbia and Utah. Journal of Systematic Palaeontology 11: 743-787 DOI 10.1080/14772019.2012.732723.

Daley AC, Drage HB. 2016. The fossil record of ecdysis, and trends in the moulting behaviour of trilobites. Arthropod Structure \& Development 45: $71-96$ DOI 10.1016/j.asd.2015.09.004.

Daley AC, Paterson JR, Edgecombe GD, García-Bellido DC, Jago JB. 2013. New anatomical information on Anomalocaris from the Cambrian Emu Bay Shale of South Australia and a reassessment of its inferred predatory habits. Palaeontology 56:.971-990 DOI 10.1111/pala.12029.

Drage HB. 2019. Quantifying intra- and interspecific variability in trilobite moulting behaviour across the Palaeozoic. Palaeontologia Electronica 22.2.34: 1-39 DOI 10.26879/940.

Drage HB, Daley AC. 2016. Recognising moulting behaviour in trilobites by examining morphology, development and preservation: Comment on Błażejowski et al. 2015. BioEssays 38: 981-990 DOI 10.1002/bies.201600027. 
251 Drage HB, Vandenbroucke TRA, Van Roy P, Daley AC. 2019. Sequence of post-moult 252 exoskeleton hardening preserved in a trilobite mass moult assemblage from the Lower 253 254 255

Han NR, Tang L, Wei RS, Wang GB. 2000. Stratigraphy of Upper Cambrian from Guole, Jingxi, Guangxi. Journal of Guilin Institute of Technology 20: 350-355.

Jago JB, García-Bellido DC, Gehling JG. 2016. An early Cambrian chelicerate from the Emu Bay shale, south Australia. Palaeontology 1-14 DOI 10.1111/pala.12243.

Jago JB, Haines PW. 2002. Repairs to an injured early Middle Cambrian trilobite, Elkedra area, Northern Territory. Alcheringa 26: 19-21 DOI 10.1080/03115510208619241.

Kimmig J, Pratt BR. 2018. Coprolites in the Ravens Throat River Lagerstätte of northwestern Canada: implications for the Middle Cambrian food web. Palaios 33: 125-140 DOI 10.2110/palo.2017.038.

Klompmaker AA, Kelley PH, Chattopadhyay D, Clements JC, Huntley JW, Kowalewski M. 2019. Predation in the marine fossil record: studies, data, recognition, environmental 
273 factors, and behavior. Earth-Science Reviews, 194: 472-520 DOI $274 \quad$ 10.1016/j.earscirev.2019.02.020.

275 Lerosey-Aubril R, Hegna TA, Babcock LE, Bonino E, Kier C. 2014. Arthropod appendages 276 from the Weeks Formation Konservat-Lagerstätte: new occurrences of anomalocaridids in 277 the Cambrian of Utah, USA. Bulletin of Geosciences 89: 269-282 DOI $278 \quad 10.3140 /$ bull.geosci.1442.

279 Lerosey-Aubril R, Kimmig J, Pates S, Skabelund J, Weug A, Ortega-Hernández J. 2020. 280 New exceptionally preserved panarthropods from the Drumian Wheeler 281 Konservat-Lagerstätte of the House Range of Utah. Papers in Palaeontology in press DOI $282 \quad 10.1002 / \mathrm{spp} 2.1307$.

283 Lerosey-Aubril R, Ortega-Hernández J, Zhu, XJ. 2013. The first aglaspidid sensu stricto 284 from the Cambrian of China (Sandu Formation, Guangxi). Geological Magazine 150: 565285 571 DOI 10.1017/S0016756812001045.

286

287

288

289

290

291

292

293

294

295

Lerosey-Aubril R, Pates S. 2018. New suspension-feeding radiodont suggests evolution of microplanktivory in Cambrian macronekton. Nature communications 9: 3774 DOI 10.1038/s41467-018-06229-7.

Lerosey-Aubril R, Zhu XJ, Ortega-Hernández J. 2017. The Vicissicaudata revisited--insights from a new aglaspidid arthropod with caudal appendages from the Furongian of China. Scientific Reports 7: 11117 DOI 10.1038/s41598-017-11610-5.

Mcnamara KJ, Rudkin DM. 1984. Techniques of trilobite exuviations. Lethaia 17: 153-173.

McNamara KJ, Tuura ME. 2011. Evidence for segment polarity during regeneration in the Devonian asteropygine trilobite Greenops widderensis. Journal of Paleontology 85: 106110 DOI 10.2307/23019504. 
296 Nedin C. 1999. Anomalocaris predation on nonmineralized and mineralized trilobites. Geology

297 27: 987-990 DOI 10.1130/0091-7613(1999)027\%3C0987:aponam\%3E2.3.co;2.

298 Owen AW. 1985. Trilobite abnormalities. Transactions of the Royal Society of Edinburgh:

$299 \quad$ Earth Sciences 76: 255-272 DOI 10.1017/s0263593300010488.

300

301

302

303

304

305

306

307

308

309

310

311

312

313

314

315

316

317

318

Pates S, Bicknell RDC. 2019. Elongated thoracic spines as potential predatory deterrents in olenelline trilobites from the lower Cambrian of Nevada. Palaeogeography, Palaeoclimatology, Palaeoecology 519: 295-306 DOI 10.31233/osf.io/2jr9c.

Pates S, Bicknell RDC, Daley AC, Zamora S. 2017. Quantitative analysis of repaired and unrepaired damage to trilobites from the Cambrian (Stage 4, Drumian) Iberian Chains, NE Spain. Palaios 32: 750-761 DOI 10.2110/palo.2017.055.

Pates S, Botting JP, McCobb LM, Muir LA. 2020. A miniature Ordovician hurdiid from Wales demonstrates the adaptability of Radiodonta. Royal Society Open Science 7: 200459 DOI 10.1098/rsos.200459.

Peng SC. 2009. Review on the studies of Cambrian trilobite faunas from Jiangnan slope belt, South China, with notes on Cambrian correlation between South and North China. Acta Palaeontologica Sinica 48: 437-452.

Pratt BR. 1998. Probable predation on Upper Cambrian trilobites and its relevance for the extinction of soft-bodied Burgess Shale-type animals. Lethaia 31: 73-88 DOI 10.1111/j.1502-3931.1998.tb00493.x.

Rudkin DM. 1979. Healed injuries in Ogygopsis klotzi (Trilobita) from the Middle Cambrian of British Columbia. Royal Ontario Museum, Life Sciences Occasional Paper 32: 1-8.

Rudkin DM. 1985. Exoskeletal abnormalities in four trilobites. Canadian Journal of Earth Sciences 22: 479-483 DOI 10.1139/e85-047. 
319 Schoenemann B, Clarkson ENK, Høyberget M. 2017. Traces of an ancient immune system 320 how an injured arthropod survived 465 million years ago. Scientific Reports 7: 40330 DOI 10.1038/srep40330.

322

323

324

325

326

327

328

329

330

331

332

333

334

335

336

337

338

339

340

Šnajdr M. 1985. Anomalous exoskeletons of Bohemian encrinurine trilobites. Vestník Úsredního Ústavu Geologického 60: 303-306.

Stein M. 2013. Cephalic and appendage morphology of the Cambrian arthropod Sidneyia inexpectans. Zoologischer Anzeiger 253: 164-178 DOI 10.1016/j.jcz.2013.05.001.

Van Roy P, Daley AC, Briggs DE. 2015. Anomalocaridid trunk limb homology revealed by a giant filter-feeder with paired flaps. Nature 522: 77-80 DOI 10.1038/nature14256.

Vannier J. 2012. Gut contents as direct indicators for trophic relationships in the Cambrian marine ecosystem. PLoS One 7: e52200 DOI 10.1371/journal.pone.0052200.

Vannier J, Chen JY. 2005. Early Cambrian food chain: new evidence from fossil aggregates in the Maotianshan Shale biota, SW China. Palaios 20: 3-26 DOI 10.2110/palo.2003.p03-40.

Whittington HB, Briggs DEG. 1985. The largest Cambrian animal, Anomalocaris, Burgess Shale, British Columbia. Philosophical Transactions of the Royal Society of London. Series B, Biological Sciences 309: 569-609 DOI 10.1098/rstb.1985.0096.

Yang J, Ortega-Hernández J, Drage HB, Du KS, Zhang XG. 2019. Ecdysis in a stem-group euarthropod from the early Cambrian of China. Scientific Reports 9: 5709 DOI 10.1038/s41598-019-41911-w.

Zacaï A, Vannier J, Lerosey-Aubril R. 2016. Reconstructing the diet of a 505-million-year-old arthropod: Sidneyia inexpectans from the Burgess Shale fauna. Arthropod Structure \& Development 45: 200-220 DOI 10.1016/j.asd.2015.09.003. 
341 Zamora S, Mayoral E, Esteve J, Gámez-Vintaned JA, Santos A. 2011. Exoskeletal 342 abnormalities in paradoxidid trilobites from the Cambrian of Spain, and a new type of bite 343 trace. Bulletin of Geosciences 86: 665-673 DOI 10.3140/bull.geosci.1275.

344 Zamora S, Sumrall C, Zhu, XJ, Lefebvre B. 2017. A new stemmed echinoderm from the 345 Furongian of China and the origin of Glyptocystitida (Blastozoa, Echinodermata). $346 \quad$ Geological Magazine 154: 465-475 DOI 10.1017/S001675681600011X.

347 Zamora S, Zhu XJ, Lefebvre B. 2013. A new Furongian (Cambrian) echinoderm-Lagerstätte 348 from the Sandu Formation (South China). Cahiers de Biologie Marine 54: 565-569.

349 Zhai DY, Edgecombe GD, Bond AD, Mai HJ, Hou XG, Liu Y. 2019. Fine-scale appendage 350 structure of the Cambrian trilobitomorph Naraoia spinosa and its ontogenetic and 351 ecological implications. Proceedings of the Royal Society B: Biological Sciences 286: 352 20192371 DOI 10.1098/rspb.2019.2371.

353

354

355

356

357

358

359

360

361

Zhan RB, Jin JS, Rong JY, Zhu XJ, Han NR. 2010. Late Cambrian brachiopods from Jingxi, Guangxi Province, South China. Alcheringa 34: 99-133 DOI $10.1080 / 03115510903522872$.

Zhou TM, Liu YR, Meng XS, Sun ZH. 1977. Class Trilobita, In: Palaeontological atlas of Central and South China. 1, Early Palaeozoic. Beijing: Geological Publishing House, 104266.

Zhu XJ. 2005. Trilobite faunas from Cambrian Upper Furongian of Guangxi with special notes on malformation, dimorphism and the function of eye ridges. Ph.D. Thesis, Nanjing Institute of Geology and Palaeontology, Chinese Academy of Sciences, Nanjing. 
362 Zhu XJ, Hughes NC, Peng SC. 2007. On a new species of Shergoldia Zhang, Jell, 1987

363 (Trilobita), the family Tsinaniidae and the order Asaphida. Memoirs of the Association of $364 \quad$ Australasian Palaeontologists 34: 243-253.

365 Zhu XJ, Hughes NC, Peng SC. 2010. Ventral structure and ontogeny of the late Furongian 366 (Cambrian) trilobite Guangxiaspis guangxiensis Zhou, 1977 and the diphyletic origin of the 367 median suture. Journal of Paleontology 84: 493-504 DOI 10.1666/09-070.1.

368 Zhu XJ, Peng SC, Du SX, Hu YS. 2007. Ontogeny and malformation of Tamdaspis jingxiensis 369 sp. nov. (trilobite, Cambrian) from Jingxi, Guangxi, China. Acta Palaeontologica Sinica 46: $370 \quad 225-231$.

371 Zhu XJ, Peng SC, Zamora S, Lefebvre B, Chen GY. 2016. Furongian (upper Cambrian) 372 Guole Konservat-Lagerstätte from South China. Acta Geologica Sinica (English Edition) 90: 373 30-37 DOI 10.1111/1755-6724.12640.

374 Zhu XJ, Zamora S, Lefebvre B. 2014. Morphology and palaeoecology of a new edrioblastoid 375 (Edrioasteroidea) from the Furongian of China. Acta Palaeontologica Polonica 59: 921376 926 DOI 10.4202/app.2012.0116.

377 Zong RW. 2020. Abnormalities in early Paleozoic trilobites from central and eastern China. $378 \quad$ Palaeoworld in press DOI 10.1016/j.palwor.2020.07.003. 
Figure 1

(A) Map of fossil locality at Guole Town, Jingxi County, Guangxi, South China; (B) Stratigraphic sketch showing relative position and age of the Sandu Formation.

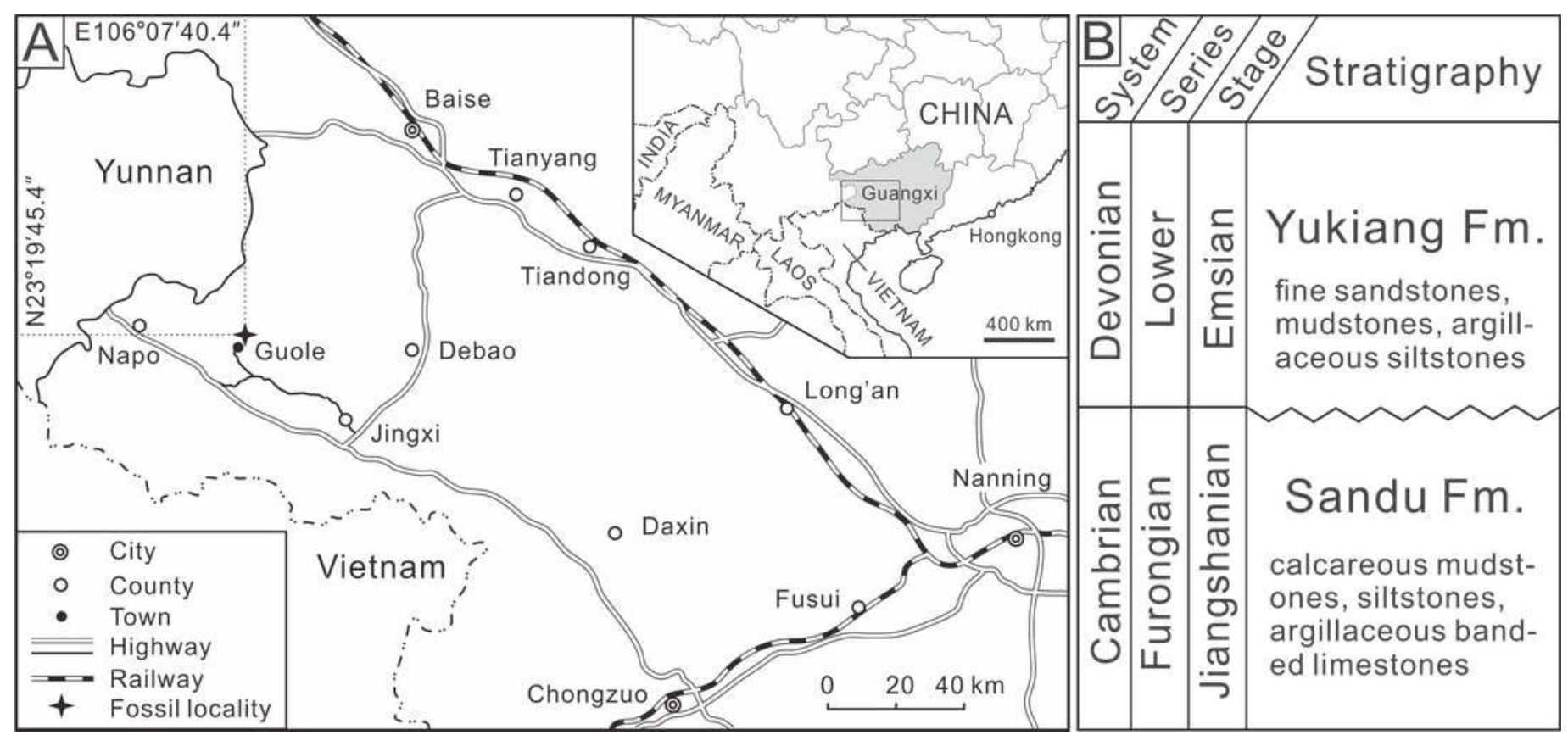




\section{Figure 2}

Malformed trilobite Shergoldia laevigata from the Cambrian Furongian of Jingxi, Guangxi (Specimen No. CUG-GJ-2015-01).

(A) Uncoated specimen; (B) close-up of abnormality in box in figure (A); (C) specimen

whitened by the magnesium powder; (D) sketch of the figure (A); (E) picture after recovery of the cranidium and the first three thoracic segments, showing the superposed relationship between the posterior area of the fixigena and thoracic segments. 

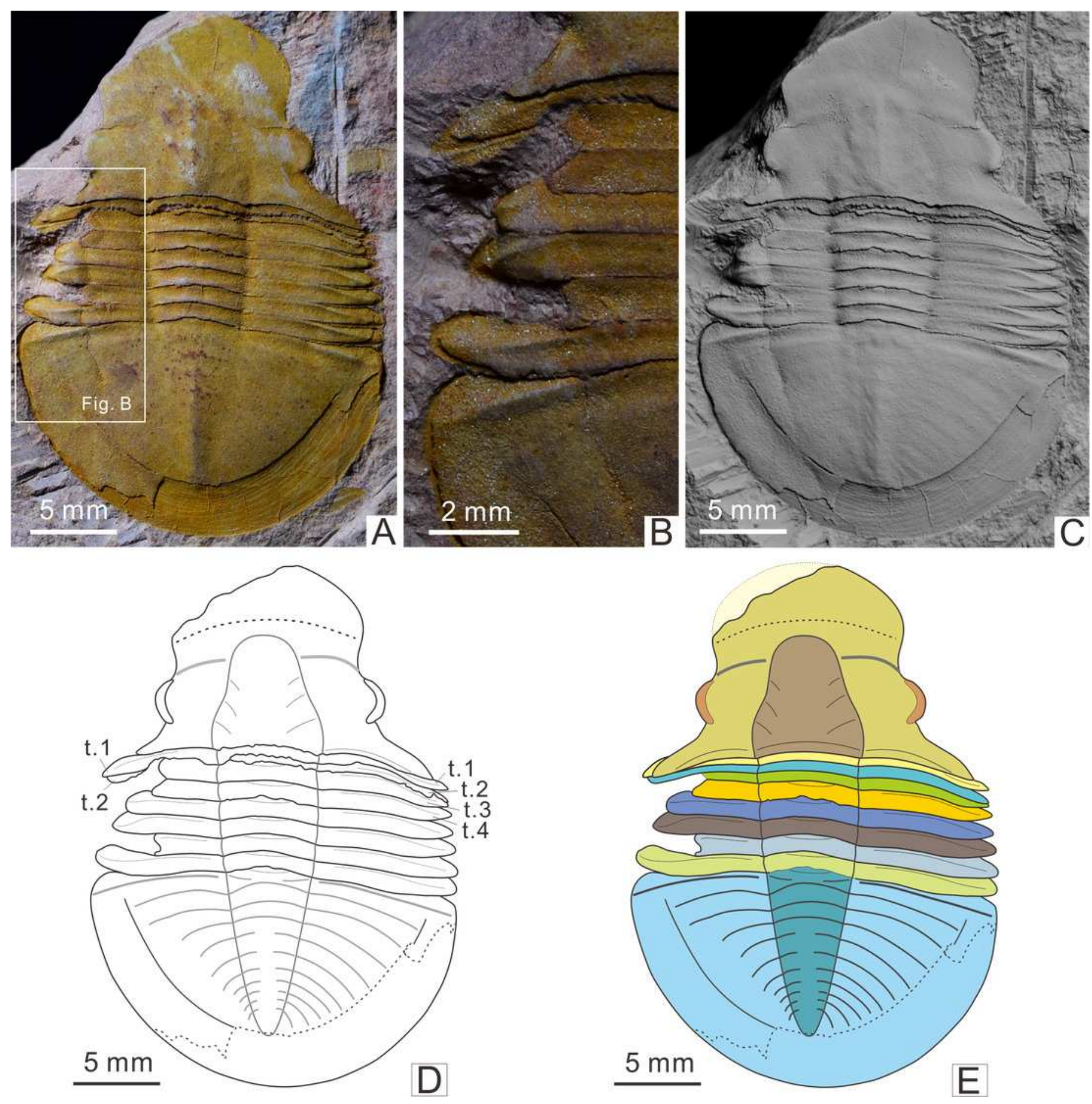


\section{Figure 3}

Reconstruction of injured of studied Shergoldia laevigata specimen from the Cambrian Furongian of Jingxi, Guangxi.

(A-B) Predator attack on Shergoldia laevigata, and leading to damage in the exoskeleton. (C) Shergoldia laevigata drag forward the old shell during molting, because of the deformation of the exoskeleton. Such condition leads to the overlap of somites and dislocated arrangement of thoracic segments. 


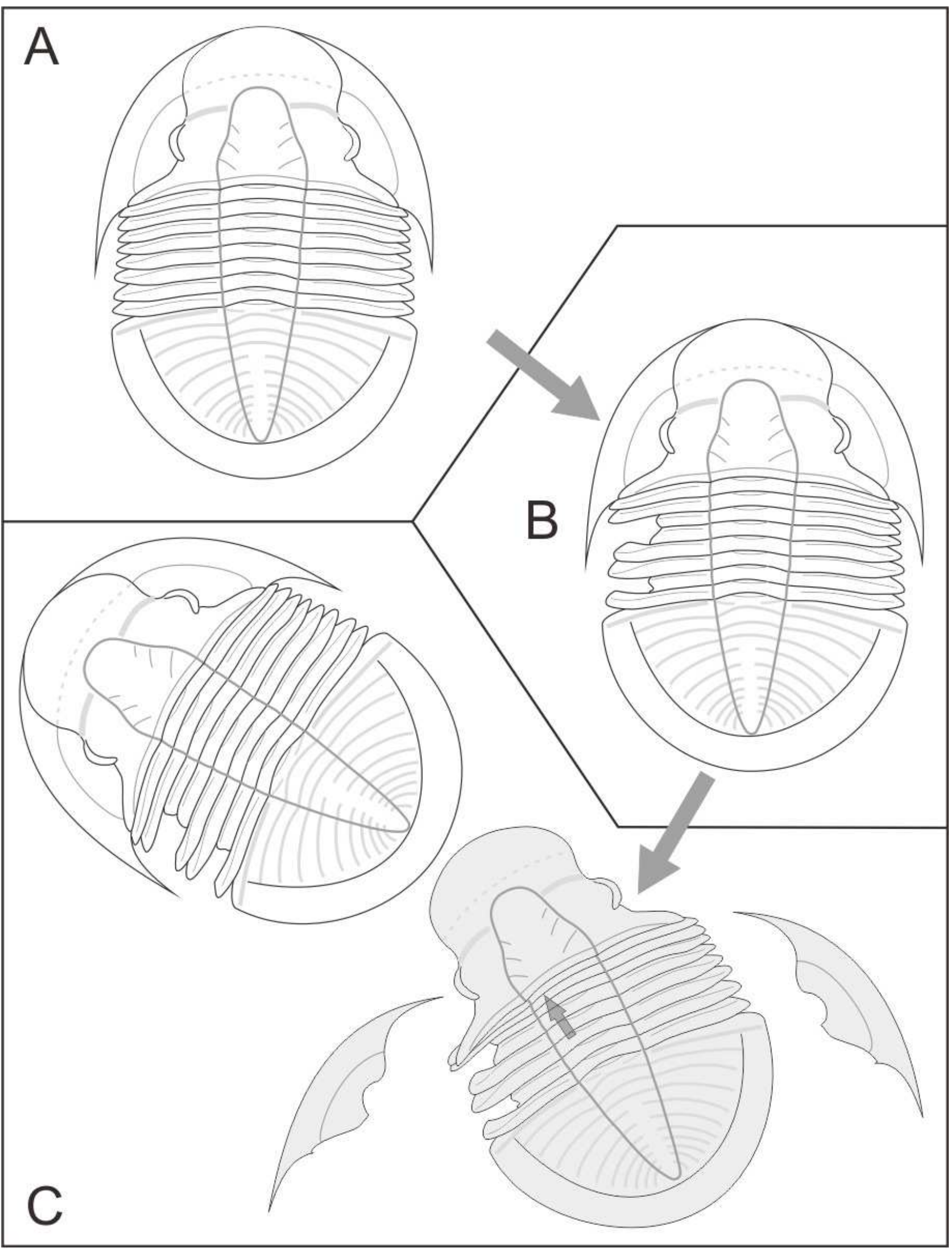

